\title{
Institutional Discrimination against the Minority Groups in Bosnia and Herzegovina: Barrier to EU Membership
}

\author{
Bedrudin Brljavac \\ University of Sarajevo \\ Bosnia and Herzegovina
}

\section{Democracy without Minority Groups and Non-nationalists}

Following widespread democratization processes in Eastern and Central Europe, in November 1990 the first multi-party elections were held in Bosnia and Herzegovina (hereinafter, Bosnia or $\mathrm{BiH}$ ). These elections were among the first indicators that marked the democratic transition of the country from the communist regime to liberal democracy. However, political parties in the country were allowed to be organized along ethnic lines resulting in the nationalist parties together collecting $84 \%$ of the vote (Arnautović, 2007: 7). Thus, an organization of the first democratic elections in the country marked the start of the political hegemony of nationalist political parties as the majority of the electorate voted for nationalist parties; that is, Bosniaks voted for Party of Democratic Action (SDA), Bosnian Serbs for Serbian Democratic Party (SDS), and Bosnian Croats for the Croatian Democratic Union (HDZ) (Freedom House, 2010: 122). To illustrate, even the post-election distribution of power was based upon ethnic principles so that the President of the Republic of Bosnia and Herzegovina was a Bosniak, president of the Parliament was a Serb, and the prime minister was a Croat representative. Furthermore, the war that broke out in 1992 further increased ethnic hatred and intolerance, resulting in ethnicity and ethnic solidarity as a dominant social and political cleavage.

That is, the conflict between the three ethnic groups intensified inter-ethnic polarization and massively strengthened the political domination of ethnonationalist political parties in the decision-making processes. What's more, the Dayton Peace Agreement, signed in 1995, not only created an extremely cumbersome policy process that would frequently result in deadlock, it also left unresolved the conflicts that had come to the fore in the 1992-1995 war and enshrined the ethno-nationalist principle as the foundation of public discourse 
(Vogel, 2006: 2). While the DPA brought the war to an end and laid the foundation for consolidating peace, many observers also believe that the agreement as a document reflects wartime circumstances cannot by itself ensure BiH's future as a functioning and democratic state (Ashdown, 2005). Thus, the post-war political and social space has been largely dominated by three ethnic groups, leading to institutional marginalization of minority groups and their members. In the postDayton Bosnia the majority of citizens are in a position of "homo duplex," or a divided human, since they are in a struggle between being a genuine human being and loyal ethnic being. While the transition to democracy should bring about participation and inclusion of diverse groups into public policy-making, the postwar Bosnian public sphere has been dominated by an ethno-political matrix causing discrimination against minority groups.

What is more, such an discriminatory political system is in clear conflict with the country's efforts to enter the European Union in the foreseeable future. In fact, in the end of 1990s through the newly initiated Stabilization and Association Process (SAP), the European Union aimed to encourage the path of the region's states, including $\mathrm{BiH}$, in integration into political and economic structures of the Bloc (Becker, 2008: 20). Additionally, in June 2000 in the Feira European Council it was decided that all the SAP countries, including Bosnia, are potential candidates for EU membership. Following a difficult reform process Bosnia and Herzegovina signed the Stabilization and Association Agreements (SAA) with the EU in June 2008 which was the first pre-accession tool for this Balkan country towards its eventual EU membership. Thus, for $\mathrm{BiH}$ and for the whole Western Balkans, the EU-related reform process means adjustment to advanced western models as well as security and prosperity for the future (Anastasakis, 2005: 80). In other words, the so-called Europeanization process has influenced the political, economic, administrative and social policy-making in the country.

Thus, Kubicek $(2005,374)$ claims that the process of Europeanization not only guarantees new opportunities for societal forces that had been previously excluded from the policy-making, but it also contributes to transformation of other structural elements such as a political ideology (identity politics), the legal framework, and the party system, and triggers changes in them all, finally resulting in internal reforms. Furthermore, Ladrech (1994) mentions the transformative power of the Europeanization process influencing citizenship and national identity. However, it is highly debatable to what extent the Europeanization process in Bosnia has influenced the idea of citizenship since minority groups and non-national members are widely marginalized both on state and society levels. Although there have been a number of difficult problems slowing down Bosnia's EU reform process, widespread ethnic polarization and omnipresent ethnic domination over the public 
sphere have become the most staggering challenges on the country's route to Brussels. That is, the current Bosnian ethno-political arrangement has limited realization of citizens' individual identity that should be an essential part of the Europeanization process. The post-war Bosnia has mostly been closer to the process of 'Balkanization' that is viewed as contrary to what may be 'western' values and norms (Todorova, 1994).

\section{Jurgen Habermas's Theory of Citizen Recognition}

What's more, one of the main objectives of establishing the European Community (later European Union) was to reduce disintegrative and harmful influences of nationalists and thus integrate the European countries into a peaceful, prosperous, and secure community. That is, a peaceful and harmonious coexistence between different national, linguistic, religious, sexual, and racial groups has been encouraged in the EU institutional framework (Zofia Wilk-Woœ, 2010: 79). Especially at the beginning of the 1990s the EU intensified its activities in the field of minority protection prior to the enlargement of the Central and Eastern European countries. Thus, in June 1993 the European Council held in Copenhagen agreed on the so-called Copenhagen Criteria that, among other things, emphasizes the protection of minority groups. That is, the EU's Copenhagen political criteria require candidate countries to achieve "stability of institutions guaranteeing democracy, the rule of law, human rights and respect for and protection of minorities" (Harryvan \& van der Harst, 1997: 285). This being said, the applicant countries are supposed to implement necessary reforms and pass the laws that will effectively protect minority groups.

Thus, the Copenhagen Criteria has considerably contributed to extension of individual rights because it cemented the agreement that "persons belonging to national minorities can exercise and enjoy their rights individually as well as in community with other members of their group" (OSCE, 1990). Additionally, Article 12 of the TEC had prohibited discrimination based on national identity. Following the Amsterdam Treaty, Article 13 of the TEC forbids discriminatory acts on the basis of the eight following grounds: sex, racial or ethnic origin, religion or belief, disability, age or sexual orientation. Most importantly, in the Treaty of Lisbon the minority groups were legally recognized in the text of EU primary law (FRA, 2010, 46). Thus, in Article 1a it was stated that the rights of persons belonging to minority groups have become the central values and principles that the EU protects. Furthermore, the EU Fundamental Rights Charter paves the way for the principle of the non-discrimination and encourages the member states to protect 
religious, cultural and linguistic diversity (Vouters, 2001). This brought the EU much closer to its visionary ideal of "Unity in diversity."

On the other side, contemporary Bosnian public life has been marked by extensive exclusive political modus vivendi based one extreme violation of fundamental human rights marginalizing both the citizens that do not sympathize with nationalist politics and the members of minority groups. Thus, the post-Dayton political model has been concerned with the extent and nature of political participation of the citizens belonging to the three largest nations in the country. In order to thoroughly comprehend and analyze the process of political participation of the citizens in the country, Jurgen Habermas's notion of citizen recognition provides adequate theoretical framework as a basis for constructive debate. For instance, Habermas examines cases where cultural or national identity of citizens prevents their political participation in the public sphere with the rest of society, denying them the basic human rights. According to Habermas, in the public spaces characterized by serious violation of basic human rights by other citizens there exists "an incomplete or unequal inclusion of citizens, to whom full status as members of the political community is denied" (2005: 16). Simply put, Habermas supports the thought that democracy is only possible with widespread presence of inclusive participation in a society.

That's why Habermas has strongly defended democratic principles such as popular sovereignty, rule of law, constitutionally guaranteed rights, and civil liberties as an indispensable component of the open and democratic regime. Therefore, Habermas argues that constitutions are the basis for creating peaceful and democratic society in heterogeneous contexts. In this regard, he also points out that it is the constitutional principles based on a rule of law that unite and integrate the citizens of a society in which there is a wealth of social, cultural, national, philosophical values and ideas (2003). That is, an inclusive constitution is the basis of democratic order in every free and open society. As O'Neill points out: "no citizen, or group of citizens, should be excluded from a democratic process of legitimation. Relevant interests and needs, values and aspirations, convictions and conceptions of identity, must somehow all be factored into our law-making procedures" (2000: 1). Therefore, societies perceiving themselves as democratic can not set up political order on exclusionary or discriminatory constitutional principles or marginalizing social mindset. 


\section{Hegemony of Ethno-nationalist Elites}

More than 15 years since the Dayton Agreement was signed, political tensions are still omnipresent across Bosnian society, and national leaders are challenging the Peace Accord more openly and more harshly than ever before. That is, in the postDayton Bosnia the exclusive ethno-nationalist approach to politics has managed to gain the upper hand over reconciliation and consensus (Bianchini, 2000: 79). Thus, $\mathrm{BiH}$ is still far from the functioning and democratic state that the accord had envisioned. Today the country still consists of three de facto mono-ethnic territories, three education systems and a national government where ethnic key is the rule of the game. In fact, the whole state structure is built according to an omnipresent ethno-nationalist model. Therefore, the three majority ethnic groups dominate the public discourse in every aspect of life excluding minorities and nonnationalists. The best example is the Bosnian rotating presidency consisting of three members: one Bosniak, one Croat and one Serb, each of whom must be directly elected in their respective entity. That is, the Bosnian constitution is treating non-ethnic members of its community as aliens or apostates. What is more, under such a political regime it is shameful and sometimes even dangerous to declare yourself as non-nationalist or minority member.

In fact, as stated in the Dayton Agreement, the Constitution of $\mathrm{BiH}$ prevents candidacy of "others," which are minority groups, to the Presidency and the House of Peoples on the grounds of their ethnic origins because these positions are guaranteed for the so-called 'constituent' peoples, i.e. Bosniaks, Serbs, and Croats. Thus, ethnic groups are represented as communities in different power-sharing levels institutionalizing the ethnic nationalism as a dominant political objective. The hegemony of ethno-politicians has been perpetuated by a vague and manipulative idea of "constituent peoples." As a result, minority groups and nonethnic members of Bosnian society are completely excluded from the current power-sharing model. It is a kind of heresy to claim yourself non-ethnic or a sympathizing minority identity. As Touquet and Vermeersch argue:

"These people have now been excluded from mainstream accounts of the outcomes of the recent conflict: it is not possible to be a Yugoslav, a Bosnian or an Eskimo in a situation in which ethnic nationalism has transcended all else and in which there are intensely localized variations in identity and 'national' sentiments" (2008: 280).

To put it differently, a number of scholars regularly point out that DPA was negotiated by the nationalist actors, who actually were one of the main causes of the war, and thus it just extended the power of the ethic-nationalist parties and their 
leaders (Kaldor, 1997: 28-30). Bosnian citizens who do not belong to the so-called "constituent peoples" were forgotten during the negotiations in Dayton and later completely excluded from the institutional framework. Thus, the so-called "others" in the Bosnian constitution, namely Jews, Roma and all other national minorities, together with those who do not declare affiliation with the three ethnic groups, have become citizens without institutional space to exercise their political and social rights. Given such unlawful provisions of the Bosnian constitution, the country has faced a deep institutional and constitutional crisis which openly threatened the idea of democratic participation. As the post-war Bosnia was designated to become an "ethnic state" in the eyes of ethno-nationalist leaders, the national minorities as an argument of genuine multi-national Bosnia have been marginalized from public space.

Thus, through extensive institutionalization of ethno-nationalization, Bosnia has become a place where only citizens declaring themselves to be nationalist have a right to take part in the country's policy-making processes. In fact, the category of "others" and non-nationalists are openly perceived as a threat to the power-sharing model of rotation where three ethnic groups choose their representatives respectively. The "rotation model" is a clear mechanism of political engineering in order to achieve the objective of ethnically-divided Bosnia. Thus, democratic participation in the country is competition between ethnicities or ethnic communities rather than a race of equal personalities having the right of vote. As a result, the post-war hegemony of ethno-nationalists has paradoxically resulted in increasing democratic deficit of the country. Consequently, all those that belong to the category of "others" who number 17 in BiH-- namely Albanians, Montenegrins, Czechs, Italians, Jews, Hungarians, Macedonians, Germans, Polls, the Roma, Romanians, Russians, Ruthenians, Slovaks, Slovenians, Turks and Ukrainians (Hammarberg, 2010: 6)-- are playing a role of mere spectators during democratic elections. In this way, the "others" and non-nationalists among the Bosnian population have become "strangers in their own country."

\section{Exclusion of the Minority Members from the Policy-Making Process}

The Dayton Agreement resulted in a power-sharing structure dividing Bosnia into two "ethnic" entities, the Bosnian Serb-populated Republika Srpska, and Bosniakand Croat-populated Federation of Bosnia and Herzegovina. Also, at the state level there is a rotating presidency consisting of three ethnic representatives respectively and a state parliament, both of which are superior to the entity institutional structures. Nevertheless, as stated in the Dayton Agreement, the Constitution of 
BiH prevents candidacy of "others," which are minority groups, to the Presidency and the House of Peoples on the ground of their ethnic origins because these positions are guaranteed for the so-called 'constituent' peoples, i.e. Bosniaks, Serbs, and Croats. This includes national minorities who have lived in Bosnia and Herzegovina for centuries (Claridge, 2010: 1). This power-sharing arrangement has considerably contributed to the process of ethno-nationalization since non-ethnic elements are completely excluded from the political participation in the country where they were born. That is, the citizens from minority groups such as the Roma, Turks, or Jews are granted only a limited degree of self administration (Soberg, 2008: 715). Although BiH joined the Council of Europe on 24 April 2002, there has been increasing discrimination against minorities in the country.

By forbidding minority members to run for office the Bosnian constitution violates fundamental human rights, though in 2002 its government ratified the ECHR and its Protocols. Thus, Jakob Finci and Dervo Sejdić, who are respectively Jewish and Roma by their ethnicity, contested these provisions before the ECHR since they were banned from running for office. On December 2009 the Court ruled that the exclusion of minority groups from Bosnia's highest elected offices constituted unjustified discrimination. Thus, "the European Court has made it clear that racebased exclusion from political office has no place in Europe," said Clive Baldwin, senior legal advisor at HRW (Guardian, 2009). If correctly implemented, the decision of the ECHR will assist in breaking down ethnic and religious divisions in Bosnia and Herzegovina by encouraging political participation and representation, and promoting social cohesion (Claridge, 2010: 2). However, two years have passed from the Court decision and the country's politicians have not yet removed discriminatory provisions from the constitution due to their different ethnic interests. As a result, Bosnia is still a profoundly undemocratic country. While most of Europe is going towards multi-national structures Bosnia is still pushing ethno-nationalization.

For instance, the Roma problem in the country is the most illustrative case. Although in 2008 Bosnia and Herzegovina adopted the Action Plan to Address the Problems of Roma in Employment, Housing and Healthcare, this minority group is still highly marginalized. Similarly, both in the pre-war and the post-war Bosnia the Roma have been one of the most marginalized and repressed minority groups. According to the Roma NGOs, 75,000-100,000 Roma are living in BiH and they are considered to be one of the largest national minorities in the country. Although the country is on the way to the European Union there has been has been profound discrimination against Roma from education, employment, and health to political representation. For instance, Roma are the most numerous ethnic group amongst the homeless in $\mathrm{BiH}$. More than $70 \%$ of Roma do not have a house, while the rate 
of Roma returnees is very low (2009). According to a 2007 report by UNICEF, up to $80 \%$ of Roma children in Bosnia and Herzegovina do not attend school; only $20 \%$ of Roma participate in secondary education, and less than $1 \%$ in higher education (2007). The proportion of Roma employed within the public sector in Bosnia and Herzegovina is estimated at 2-3\%.Thus, they are discriminated against even in terms of basic human rights.

In addition, even in the media the Roma members are degraded and described as "problematic," "violent," "dangerous," etc. For instance, when an incident involving the Roma happens, their full names are given in sensational headlines, even if they are minors, with almost an obligatory remark that they belong to the Roma minority (Turcilo, 2009). In addition, the Council of Europe Commissioner for Human Rights, Mr. Thomas Hammarberg, and his delegation visited Bosnia and Herzegovina from 27 to 30 November 2010 in order to evaluate the living conditions of minority groups in $\mathrm{BiH}$. As far as the Roma minority is concerned, the Delegation summarized that their lifestyle prevented the state from including them in statistics. The government knows they live in difficult situations and is serious about this issue. But the delegation said the question was more one of prejudice than discrimination (2011). Further, the Delegation recommended to the Bosnian government to intensify efforts in order to improve the social and economic conditions of the Roma community drawing upon the Council of Europe Committee of Ministers' Recommendation on the Policies for Roma and/or Travelers in Europe (CM, 2008).

\section{Institutionalization of Ethno-nationalist Paradigm}

In addition, in Bosnia the education system has been widely utilized by the ruling ethno-nationalists to strengthen their ethnic hegemony. In fact, ethnic leaders have not demonstrated necessary political will and commitment to establish genuine multi-ethnic schools. What is more, education policies have played significant role in the promotion of ethnic segregation. As the European Commission pointed out in its 2009 Progress Report for BiH: "Divisions in the education system through continuous development of mono-ethnic schools in both entities are still a matter of concern and result in de facto segregation of pupils from the very beginning of their schooling" (2009). For instance, the educational system in the Federation of $\mathrm{BiH}$ is built on the model of "two schools under one roof" where children from two ethnic groups, Croats and Bosniaks, attend classes in the same building, but are physically separated from each other and taught separate curriculum. Today, there are 57 such schools in this part of Bosnia. Some ethnic politicians oppose 
integrated multi-ethnic schools free from political, religious and any other discrimination, arguing they would lose their ethnic identity by mixing with others. Ethno-nationalists have used education for the systematic indoctrination of their respective ethnic groups.

What is more, the education system in $\mathrm{BiH}$, instead of playing the role of an integrative platform in which democratic values and norms are being taught, has been under the vehement influence of ethno-nationalist political elites resulting in serious discrimination of minority groups. Put simply, the children of minority groups in Bosnia have been the collateral damage of the ethno-nationalist policymaking in the sphere of education. On the other hand, the OECD stresses in its report published in September 2001 that "education systems should not just be 'fair' to minorities - they should promote a spirit of equality and tolerance among ethnic and cultural groups" (2001). However, in the post-Dayton Bosnia minorities have become "invisible" in the education system which is hammering out ethnonationalist paradigm. As Valery Perry argues:

"Let us take a look at language. The official language in the Republika Srpska is Serbian, and in the Federation the official languages are Bosnian or Croatian, depending on the canton. The 'others' learn the language that is dominant in their particular surrounding. It is worth stressing that we have three official languages in one country. 'Others' have been assimilated into an official language, but only the language of their specific territory, which in my opinion is not in accordance with their human rights." (2002: 27)

Probably the marginalization of minority groups from the Dayton negotiations and from the agreed accord conception was a result of a speedy reaction to end the war and find a difficult compromise solution. The most important thing was to end the horrible war and find a power-sharing model in which each ethnic group would take part without being discriminated and dominated by other two groups respectively. That is, the main objective of the Dayton negotiations was peace rather than equality, thus discriminating against non-nationalist groups. As the European Court of Human Rights concluded in their ruling concerning the SejdicFinci case:

"a very fragile cease-fire was in effect on the ground. The provisions were designed to end a brutal conflict marked by genocide and 'ethnic cleansing'. The nature of the conflict was such that the approval of the "constituent peoples' ... was necessary to ensure peace. This could explain, without necessarily justifying, the absence of representatives of other communities $\ldots$ at the peace negotiations and the participants' preoccupation with 
effective equality between the 'constituent peoples' in the post-conflict society" (2009: 34).

As a result, $\mathrm{BiH}$ has become a bi-cameral legislature where the three so-called “constituent peoples," Bosniaks, Serbs and Croats, are represented in parity (5:5:5) in the second chamber, the House of Peoples (Marko, 2005: 6). In addition, both state presidency and national government with ministers and their deputies are composed according to the ethnic power-sharing. Thus, the post-Dayton institutional framework is to a large extent based on the consociationalist model of power-sharing (Lipjhart, 1994). Consociationalism is a form of power-sharing whose main purpose is reconciliation of diverse social preferences along ethnic and religious lines (Schneckener 2002: 203-206). In other words, the Dayton Agreement has resulted in an institutional framework in which the largest three ethnic groups are officially recognized in the constitution and which take equal part at all administrative decision-making levels, also enjoying the same right of veto when their respective "vital national rights" are endangered (Bieber, 2004). However, the consociationalist model of power-sharing in Bosnia has not brought about necessary democratic transformation and reconciliation even after the period of 15 years of transition. What is more, while envisaged to keep the equilibrium between three ethnic groups the Dayton-based consociationalist model completely excluded minority members and non-nationalists from the decision-making process.

\section{Institutional Engineering Killing the Idea of Citizenship}

Thus, the post-war power-sharing order in Bosnia has heavily relied on the constituent ethnic groups. However, weak performance of democracy and ethnic tolerance under the current rules reveals limits of institutional engineering (Manning \& Antić 2003, 55-56). It is of crucial importance to apply institutional engineering in post-conflict societies in order to bring peace and stability among warring fractions. In fact, institutional engineering is the art of providing for rules and institutions in order to pursue political goals - such as creating a functioning multi-ethnic democracy (Reilly 2001; Grofman \& Stockwell 2003). Nevertheless, the war in Bosnia was thought to end through ethnic balance of power-sharing which resulted in a political concept that was counterproductive, further increasing ethnic tensions among warring groups. As Prof. Zarije Seizovic points out: "The "ethnic criteria" introduced in the Preamble of the Constitution of $\mathrm{BiH}$ (being reinforced in number of places in its normative part) prevents $\mathrm{BiH}$ authorities from sharing power equally within the civil society, favouring ethnic groups to the 
detriment of the individual citizen" (2007: 2). In fact, such a power-sharing model has been viewed in essentialist and absolutist terms by ethnic groups as a clear example of the zero-sum game.

In fact, while minority groups were completely marginalized during the negotiations among warring ethnic groups, their presence and political inclusion could be utilized for the development of a democratic and open system of governance. While today after the ruling of the ECHR they have become a huge problem for the country's integration into Euro-Atlantic associations they could actually be a part of a long-term solution. In fact, the Constitution of $\mathrm{BiH}$ recognizes basic human rights and protection of minority groups and requires the State institutions and both Entity governments to ensure the highest level of internationally recognized human rights and freedom from discrimination (Art. II 4). Yet in practice, all the country's citizens do not enjoy human rights and fundamental freedoms on an equal basis. That is, the current constitutional order was unsuccessful from the very outset in $\mathrm{BiH}$, as it has not provided for protection of individual citizens but their collective identity (Seizovic, 2007: 2). Were the minority protected from the discriminatory acts the whole concept would turn from ethnic to civic, eradicating the ethnic homogenization as a main source of political and social tensions in Bosnia. This would lead to strengthening of universal human rights as prescribed by the liberal-democratic order.

Following the ethnic conflict in 1992-1995 and the post-war domination of the ethno-nationalist paradigm the citizenship in Bosnia has acquired unique features based extensively on the primacy of group rights over individual rights. In fact, the Dayton constitutional framework guarantee both state and entity citizenship for the population in Bosnia and Herzegovina. That is, acquisition of the entity citizenship has further intensified the process of ethnic homogenization and also exclusion of non-ethnic elements in the country. As Sarajlic points out:

"In addition to the malaise of postsocialist transition, shared by all the Yugoslavian successor states, the existing Bosnian citizenship regime has been strongly influenced by a heritage of ethnic conflict and the provisional constitutional set-up of the country, ... the conceptualization of citizenship in Bosnia and Herzegovina has been dependent on the definition of the community of citizens who constitute the state. Since Bosnia and Herzegovina is not a nation-state (and has never been one) but a federal union based on the sovereignty of ethnic groups which have political supremacy over individuals, making clear-cut assumptions and definitions of Bosnian citizenship is close to impossible (2010: 2). 
That's why it has become almost illogical to talk about the citizens of Bosnia and Herzegovina since more than half of the country's population do feel like Serbs, Croats, or Bosniaks rather than Bosnians. In other words, BiH political discourse has become limited and even restrictive for the members perceiving themselves as Yugoslavs, Bosnians, Romas, Jews, and so forth. In that regard, Prof. Atajic points out that, "Everything - from the greeting you use to the dialect you speak and the newspaper in your coat pocket - is judged, commented upon and categorized in terms of an omnipresent, mysticised 'ethnicity'. Under such circumstances, defining oneself as a citizen of the $\mathrm{BiH}$ state is tantamount to a betrayal of one's national identity" (2002:118). In fact, ethnicity is perceived by the vast majority of people in Bosnia as a religious dogma that has to be respected. Such a situation has produced negative consequences on the development of common Bosnian citizenship. In this context, there is also a kind of absurdity; namely, even those citizens who are Bosnians (instead of being Serbs, Bosniaks or Croats) constitute a minority in $\mathrm{BiH}$ (Turcilo, 2009: 1). In other words, every person not aligning himself/herself with one of the three ethnic groups is automatically considered a minority or a kind of foreign element.

\section{"Vital National Interest" as a Rule of the Game}

Furthermore, the interests of collectivity have dominated individual preferences of the citizens preventing development of free discussion and inclusion of non-ethnic elements of society. As Mujkic and Husley point out: "Since the first democratic elections in Bosnia and Herzegovina in 1991, politics have been characterized by ethnopolitics rather than interest-based politics. The result is that political competition for voters has been warped, with the role of voters reduced to a kind of ethnic census" (2010: 144). What's more, before the day of elections the vast majority of the members of three ethnic groups decide "collectively" to give the vote to their ethno-nationalist political parties respectively. Not only are nonnationalists and members of minority groups excluded from the public discourse, but they are very often under strong pressure to give their vote to one of the nationalist political parties. In other words, the post-war ethno-nationalization discourse has created an omnipresent "ethno-nationalist pressure" over the members of Bosnian society to identify with one of the three national groups. That is, the post-war ethno-nationalist paradigm "naturally" exerts a pressure on Bosnian Muslims, Bosnian Catholics, and Bosnian Orthodox to align with their respective nationalist political parties.

In terms of the institutional ethno-nationalization, the Bosnian system suffers from 
institutional blockades that emerge because politicians elected separately by each ethnic community do not manage to agree on compromises that can withstand the manifold veto powers (Chivvis \& Đogo, 2010). The exclusionary Bosnian institutional structure under Dayton has allowed the representatives of each of the three ethnic groups to enjoy veto power over any proposed legislation, and it created the tripartite state presidency consisting of each group and empowered each member with a veto over any legislation. While "veto power" of the ethnic representatives is their guarantee mechanism that they will be equally included in the decision-making process, it is clearly discriminating against civic interests. As Lyon claims, "the concept of "constitutionality of nationalities" permits legalized discrimination on the basis of ethnic background, and prima facie contradicts principles of the Council of Europe. Indeed, the entire constitution enshrines ethnic discrimination as a principle of law (2006: 52). In fact, each and every civic initiative is discredited by the highly institutionalized ethno-nationalist discourse.

In addition, extensive institutionalization of ethno-nationalist politics in the postDayton Bosnia has been realized through a structural framework where ethnic rights are safeguarded on the basis of the so-called "vital national interest" (VNI). That is, in the House of Peoples of $\mathrm{BiH}$ the representatives of each constituent nation have a right to block law if it is against the VNI of their respective nation. In a similar fashion, the tripartite state presidency has the power of veto on legislative decisions if they believe they represent a threat for the vital interests of their nations. However the notion of the VNI in the Bosnian case employs a rather vague sense of "national." "National" is usually interpreted simply as "ethnic" (Mujkic, 2007). Therefore, at the heart of the notion of VNI clearly lies the ethnic dimension of political representation rather than a kind of state or national interest. That's why the principle of VNI is highly discriminatory against minority groups and non-nationalists since they do not have a right to use veto in state and entity levels. Simply put, widespread politicization of ethnicity and the success of ethnically-oriented political parties are serious obstacles in front of the long-term democratization process (Chandler, 2000: 111).

The main idea behind the vital national interest was to provide a sophisticated system of checks and balances to guarantee the rights of Bosnia and Herzegovina's "constituent peoples," i.e. Bosniaks, Croats and Serbs. State and Entity constitutions establish blocking mechanisms protecting the "vital interests" of these constituent peoples (EC, 2005: 9). However, as VNI completely marginalizes each member of the society not declaring as nationalist, it is further slowing down legislative process on the country's road to the Euro-Atlantic integration. This 
power-sharing provision based on the concept of VNI has impaired the quality of Bosnian democracy where citizens are represented only as members of one of the three constituent peoples, placing ethnic representation before general interest and making "nations rather than citizens the bearers of all rights" (Katana and Igric, 2005). As stated in the report of the USAID, "Bosnia's constitution enshrines the "vital national interests" of the constituent peoples and in doing so guarantees both political inclusion and exclusion by ethnicity... Bosnians filter public discourse by ethnicity, including as valid their group's views, excluding as invalid the views of other groups. The public square is available to all - one opinion, one voice and one group at a time" (2007: 6).

\section{With Democratic Deficit towards Brussels!}

Therefore, the post-war Bosnian political system does not contain democratic values such as equality and freedom and it does not ensure that all its citizens feel equal before the law and have equal access to the legislative process. As Bojkov stresses, democracy in post-war Bosnia can not be said to be constitutionally framed (2003: 60). Democracy is a form of government in which all citizens can participate on an equal basis in the decision-making process that affects their lives. The term democracy was invented in ancient Greece in the middle of the $4^{\text {th }}$ century BC to define the political order in some Greek city-states, and means "rule of people," coined from demos, meaning people, and kratos which means power. In terms of ontology of power, in the post-Dayton Bosnia the political power has been in the hands of ethnic oligarchies and ethnic communities as a group rather than in the hands of individual citizens. That is, Bosnian social context has been dominated by the idea of Volksgemeinshaft, or the people's community, rather than community of free individuals. In this manner, Prof. Živanović highlights the postwar political constellations in Bosnia and Herzegovina as following: "Here, we do not live as human beings but as Serbs, Croats and Bosniaks" (2005). In fact, the post-Dayton regime has dehumanized public space in Bosnia.

Thus, today's Bosnia resembles rather a kind of "illiberal democracy," as Fareed Zakaria explains the phenomenon of promotion of free elections around the world without provision of basic human rights and freedoms (1997). Thus, post-war Bosnian political regime is a kind of ethnocracy rather than representing a democratic system. An ethnocracy is a regime that facilitates "the expansion, ethnicization and control of contested territory and state by a dominant ethnic nation" (Yiftachel and Ghanem, 2004: 649). In fact, extreme prioritization of ethnic values over individual principles has been threatening to democracy. As 
Mujkic points out:

"I call a community characterized by the political priority of the ethnic group(s) over the individual that is implemented through democratic selflegislation, and a community characterized by the political priority of the ethnic group's right to self-determination over the citizen's right to selfdetermination where the citizen's membership in a political community is determined by her or his membership in ethnic community, Ethnopolis. And I call the political narrative and practice intended to justify this ethnicallybased social construct, ethnopolitics" (2007: 116).

In addition, the Dayton-based constitutional framework is in contradiction with European Union values of fundamental and human rights. Simply put, the Dayton Agreement ensures the protection of collective rights of ethnic groups while rights of minority groups have not been included into the legal framework. Thus, in March 2005 the Venice Commission proposed the range of the constitutional reforms that are necessary to prepare Bosnia and Herzegovina for future EU membership. The main recommendations that the Venice Commission made are:

- Transfer of competencies from the entities to the state,

- Reform of inefficient state legislative and executive structures,

- Elimination of "prerogatives for ethnic or group rights,"

- Strengthening citizens' rights,

- Clarification of the entities' future relationship to the state (Joseph and Hitchner, 2008: 5).

The Venice Commission also summarizes that Bosnian integration into the EU is under threat since its institutional framework is in direct breach of ECHR stated rules highlighting "the existence of tensions between a constitutional system based on collective equality of ethnic groups on one hand, and the principle of individual rights and equality of citizens on the other." (2005: 17).

Also, persons not belonging to the three biggest national groups may align with one of the three nationalist political affiliations in order to feel on equal basis with the members of the three ethnic groups. For instance, there have been high-positioned officials at state government that have preferred one of the ethnic political parties in order to "exercise their citizenship rights." However, this is not a long-term solution that can guarantee the equality of citizens in the whole country. In this regard, the Venice Commission highlights that:

"First of all, the interests of persons not belonging to the three constituent peoples risk being neglected or people are forced to artificially identify with 
one of the three peoples although they may, for example, be of mixed origin or belong to a different category. Each individual is free to change his political party affiliation. By contrast, ethnic identity is far more permanent, and individuals will not be willing to vote for parties perceived as representing the interest of a different ethnic group, even if these parties provide better and more efficient government. A system favoring and enshrining a party system based on ethnicity therefore seems flawed." (2005: 12).

\section{Concluding Remarks}

Bosnia and Herzegovina has been in the group of the former communist countries that started widespread democratic transformation in the aftermath of turbulent disintegration of Yugoslavia in early 1990s. While democratic transition in the country was expected to bring about wide participation of diverse societal groups into policy-making, the post-war Bosnian public sphere has been dominated by ethno-nationalists causing omnipresent discrimination against minority groups and those that declare themselves non-nationalists. That is, democracy brought about collectivist doctrine rather then promotion of individual rights. In addition, in spite of the fact that $\mathrm{BiH}$ is going through a deep Europeanization process in which the country's political, economic and administrative system are supposed to transform into stable, functional and democratic structures, the members of minority groups and non-nationalists are widely marginalized and excluded from the decisionmaking processes. Although the Copenhagen political criteria require applicant countries to achieve "stability of institutions guaranteeing democracy, the rule of law, human rights and respect for and protection of minorities," $\mathrm{BiH}$ is facing serious democratic deficit even today, especially with regards to widespread discrimination against minority members and people who do not feel as nationalists.

In other words, in the post-Dayton Bosnia the public sphere has become limited only for the members of the three largest ethnic groups constitutionally recognized as the so-called constituent nations. As Jurgen Habermas argues, the public space has been built on extreme marginalization of citizens as the holders of power whose status as the members of political community has been restricted. In fact, democratic participation in the country's public space has turned into a competition between ethnicities or ethnic communities rather than race of equal individuals having the right of vote. The question of ethnicity has become a raison d'être of the three ethnic groups since they believe that their physical survival depends on the 
permanent struggle for ethnic identity. Such a political model is a kind of ethnodemocracy or ethnocracy which vehemently violates human rights and fundamental freedoms and thus slows down the country's progress towards EU membership. BiH can not enter the EU while its public sphere is extremely dominated by ethno-nationalist elites that prevent development of open and democratic society. Therefore, BiH politicians, media, civil society and other proEU societal actors must make additional efforts in order to include diverse societal groups, including minority members and non-nationalists, into the decisionmaking process. Inclusion of the minority members into the policy-making process can probably turn from being a problem into a part of solution for the country's decade-long deadlock!

\section{References and Notes:}

1. Anastasakis, O, (2005), "The Europeanization of the Balkans," The Brown Journal of World Affairs, XII (1), 2005, p. 80.

2. Arnautovic, Suad. (2007), "Ten Years of Democratic Chaos: Electoral Processes in Bosnia and Herzegovina from 1996 to 2006," Sarajevo: Promocult.

3. Ashdown, Paddy, (2005), "A superb agreement to end a war, but a very bad agreement to make a state," Former HR in BiH, Lord Paddy Ashdown, Farewell, Sarajevo, The Guardian, 2 November 2005, www.guardian.co.uk/article/o..i6064.8Q.oo. $\underline{\text { html. }}$.

4. Atajic, Ramo (2002). Civilitet kroz povijest. Bihac.

5. Becker, Jens, (2008), "The European Union and the Western Balkans," South-East Europe Review, 7-27, 2008.

6. Bianchini, S., (2000), "Political Culture and Democratization in the Balkans" in Experimenting with Democracy: Regime Change in he Balkans, eds. G. Pridham and T. Gallagher, London: Routledge, 2000.

7. Bieber, F. (2004) Towards better governance with more complexity?, in: C. Solioz \& T. K. Vogel (Eds), Dayton and Beyond: Perspectives on the Future of Bosnia and Herzegovina, pp. 74-87 (Baden-Baden: Nomos).

8. Bojkov, Victor, (2003), "Democracy in Bosnia and Herzegovina: Post-1995 Political System and its Functioning," Southeast European Politics, Vol. IV, No. 1, pp. 41-67.

9. Chandler, David (2000): "Bosnia: Faking Democracy after Dayton," $2^{\text {nd }}$ edition, London: Pluto Press.

10. Claridge, Lucy, (2010), "Discrimination and political participation in Bosnia and Herzegovina, Sejdic and Finci v. Bosnia and Herzegovina," Minority Rights Group International, January 2010.

11. CM, (2008), "Recommendation CM/Rec(2008)5 of the Committee of Ministers to member states on policies for Roma and/or Travellers in Europe," available at https://wcd.coe.int.

12. EC, European Commission, (2005). "Bosnia and Herzegovina 2005 Progress Report," Brussels, 9 November 2005, available at http://ec.europa.eu/enlargement/archives/pdf/key documents/2005/package/sec 142 


\section{2 final_progress_report_ba_en.pdf.}

13. EC, European Commission, (2009). "Commission Staff Working Document, Bosnia and Herzegovina 2009 Progress Report accompanying the Communication from the Commission to the European Parliament and the Council, Enlargement Strategy and Main Challenges 2009-2010," Brussels, 14.10.2009.

14. ECHR, (2009), "European Court of Human Rights, judgment of 22 December 2009, Sejdic and Finci v. Bosnia and Herzegovina, available at http://www.ustavnareforma.ba/files/articles/20101014/192/en.\%20Case\%20of\%20S ejdic\%20and\%20Finci\%20v.\%20Bosnia\%20and\%20Herzegovina,\%2022.12.2009.p df.

15. FRA, (2010), “Annual Report 2010,” European Union Agency for Fundamental Rights, Conference Edition, available at http://fra.europa.eu/fraWebsite/attachments/AR_2010-conf-edition_en.pdf.

16. Freedom House, (2010), "Nations in Transit 2010: Bosnia and Herzegovina" prepared by Jasna Jelisic, available at http://www.freedomhouse.eu/images/Reports/NIT-2010-Bosnia-final.pdf.

17. Guardian, (2009), "Bosnia's bar on minorities in parliament ruled illegal," by Afua Hirsch, available at http://www.guardian.co.uk/world/2009/dec/22/bosnia-electionlaw-ruled-illegal, Tuesday 22 December 2009.

18. Grofman, B., \& Stockwell, R. (2003) Institutional design in plural societies: Mitigating ethnic conflict and fostering stable democracy In R. Mudambi, P. Navarra, G. Sobbrio, R. Mudambi, P. Navarra \& G. Sobrio (Eds), Economic welfare, international business and global institutional change, pp. 102-137 (Cheltenham, Elgar).

19. Hammarberg, Thomas, (2011), "Issues reviewed: Fight against discrimination, human rights of people displaced by the war, asylum seekers and stateless persons, post-war justice and reconciliation," REPORT by Thomas Hammarberg, Commissioner for Human Rights of the Council of Europe Following his visit to Bosnia and Herzegovina on 27-30 November 2010. Strasbourg, 29 March 2011.

20. Habermas, Jurgen, (2003), "Intolerance and Discrimination," Oxford University Press and New York University School of Law, 2003, I.CON., Volume 1, Number 1, 2003, p. 2-12.

21. Habermas, Jurgen (2005), "Equal Treatment of Cultures and the Limits of Postmodern Liberalism," The Journal of Political Philosophy, v. 13, n. 1, March 2005.

22. Harryvan, A.G., and J. van der Harst (New York: St. Martin's, 1997), p. 285. "Decision of the Heads of State or Government, Meeting in Copenhagen, on Future EU Enlargement," Documents on European Union.

23. Joseph, Edward P., and Hitchner, Bruce, R, (2008), "Making Bosnia Work: Why EU Accession is Not Enough," United States Institute of Peace.

24. Kaldor, Mary, (1997) 'One Year after Dayton', in Mient Jan Faber (ed.) Dayton Continued in Bosnia Herzegovina (1) (The Hague: Helsinki Citizens’ Assembly Publication Series 11).

25. Katana, G, and Igric, G, (2005), "While international players claim Bosnia's leaders 
have been secretly drafting a new constitution," Balkan Investigative Reporting Network, 18 November 2005.

26. Kubicek, P. (2005) "The Europeanization and Grassroots Democratization of Turkey" in Turkish Studies 6(3): 361-77.

27. Ladrech, Robert, (1994). "Europeanization of Domestic Politics and Institutions; the Case of France," Journal of Common Market Studies, 32 (1). P. 69-88.

28. Lipjhart, A., (1994a), Electoral Systems and Party Systems. A Study of TwentySeven Democracies 1945-1990, Oxford University Press, Oxford.

29. Lyon, James, (2006). "Overcoming Ethnic Politics in Bosnia? Achievements and Obstacles to European Integration,” in Martina, Fischer (2006), Peace building and Civil Society in Bosnia-Herzegovina. Ten Years after Dayton, Münster: Lit Verlag 2006.

30. Manning, C., \& Antić, M. (2003) The Limits of Electoral Engineering, Journal of Democracy, 14 (3), pp. 45-59.

31. Mujkić, A (2007) We, the Citizens of the Ethnopolis, Constellations Volume 14, Issue 1, 112-128.

32. Mujkic, Asim, \& Hulsey, John, (2010), "Explaining the Success of Nationalist Parties in Bosnia and Herzegovina," Politicka misao, god. 47, br. 2, 2010, str. 143158.

33. Marko, Joseph, (2005), "Post-conflict Reconstruction through State- and Nationbuilding: The Case of Bosnia and Herzegovina," European Diversity and Autonomy Papers, EDAP 4/2005, available at http://webfolder.eurac.edu/EURAC/Publications/edap/2005_edap04.pdf.

34. OECD, (2007), Centre for Co-operation with Non-members, Directorate for Education, Employment, Labour and Social Affairs, Education Committee. Thematic Review of National Policies for Education - Bosnia and Herzegovina. Stability Pact for South Eastern Europe Report, Table 1, Task Force on Education, 27 September 2001, 15.

35. O'Neill, Shane, (2000), "The Politics of Inclusive Agreements: Towards the Critical Discourse Theory of Democracy," Political Studies, 2000 Volume 48, 503-521.

36. OSCE, (1990), "Conference for Security and Co-operation in Europe," Document of the Copenhagen Meeting of the Conference on the Human Dimension of the CSCE, 5 June-29 July, available at http://aceproject.org/main/english/ei/eix_c070.htm.

37. Perry, Valery, (2002), "ECMI Civil Society Project in BiH: National Minorities and Educational Reform in Bosnia and Herzegovina," European Center for Minority Issues Workshop, Sarajevo. November, 2002.

38. Sarajlic, Eldar, (2010), "Report on Bosnia and Herzegovina," The report has been produced by the CITSEE project (The Europeanization of Citizenship in the Successor States of the former Yugoslavia) in close cooperation with EUDO CITIZENSHIP. Available at http://eudo-citizenship.eu/docs/CountryReports/ Bosnia $\% 20$ and\%20Herzegovina.pdf.

39. Schneckener, U. (2002). "Making Power-Sharing Work: Lessons from Successes and Failures in Ethnic Conflict Regulation." Journal of Peace Research 39(2): 203228. 
40. Seizovic, Zarije, (2007), “Constitutional Reform in Bosnia and Herzegovina: "“Civil State' of Constituent Peoples," This paper was presented at the Second Annual Conference on Human Security, Terrorism and Organized Crime in the Western Balkan Region, organized by the HUMSEC project in Sarajevo, 4-6 October 2007.

41. Sejdic, Dervo, (2009), "Comments on the implementation of the framework convention on the protection of national minorities in Bosnia and Herzegovina," Council of Roma of the Federation of $\mathrm{BiH}$, available at http://www.internaldisplacement.org/8025708F004CE90B/(httpDocuments)/E1DDFCE39A48E213802 570B700587783/\$file/Council+of+Roma+1.pdf.

42. Soberg, Marius, (2008), "The Quest for Institutional Reform in Bosnia and Herzegovina," East European Politics and Societies, 2008; 22; 714 originally published online Sep 8, 2008.

43. Todorova, M., (1994), "The Balkans: From Discovery to Invention," Slavic Review, 53 (2), 1994, pp. 453-482.

44. Touquet, Heleen, and Vermeersch, Peter, (2008), "Bosnia and Herzegovina: Thinking Beyond Institution-Building," Nationalism and Ethnic Politics, Volume 14, Issue 2 April 2008, pages 266 - 288.

45. Turcilo, Lejla, (2009), "Minorities in Bosnia and Herzegovina: Between Seeming Tolerance and Real Disregard," available at http://www.boell.ba/downloads/Minorities_in_BiH.pdf.

46. UNICEF, (2007), 'Breaking the Cycle of Exclusion - Roma children in South-East Europe', 2007, available at www.unicef.org.

47. USAID, (2007), "Bosnia and Herzegovina and Governance Assessment," The publication was produced for review by the United States Agency for International Development by Democracy International, Inc. May, 2007. Available at http://pdf.usaid.gov/pdf_docs/PNADK585.pdf.

48. Venice Commission, (2005), "Opinion on the Constitutional Situation in Bosnia and Herzegovina and the Powers of the High Representative," European Commission for Democracy Through Law, Venice Commission, Venice, 11 March 2005. Available at http://www.venice.coe.int/docs/2005/CDL-AD(2005)004-e.asp.

49. Vogel, Toby, (2006), "Bosnia and Herzegovina: The Challenge of Legitimacy, FAST Country Risk Profile Bosnia and Herzegovina," Working Paper 2|2006, Swiss Peace Foundation, available at http://www.swisspeace.ch/typo3/fileadmin/user_upload /Media/Publications/WP2 2006.pdf.

50. Vouters, Jan, (2001), "The EU Charter of Fundamental Rights: Some reflections on its external dimension," Institute for International Law, Working Paper No 3 - May 2001, available at https://www.law.kuleuven.be/iir/nl/onderzoek/wp/WP03e.pdf.

51. Wilk-Woœ, Zofia, (2010), "The Role of Intercultural Dialogue in the EU Policy," Journal of Intercultural Management, Vol. 2, No. 1, March 2010, pp. 78-88.

52. Yiftachel, O. and A. Ghanem, (2004), "Understanding 'Ethnocractic' Regimes: The Politics of Seizing Contested Territories," Political Geography, 23, 6:647-676, August 2004.

53. Zakaria, Fareed, (1997), “The Rise of Illiberal Democracy,” Foreign Affairs 76 
(November-December 1997): 22-43.

54. Z Živanovic, M. (2005), “U BiH Ne zivimo kao ljudi, nego kao Srbi, Hrvati i

Bosnjaci.” (2005, May 22) Oslobodjenje. Sarajevo.

\title{
SUMMARY
}

\section{Institutional Discrimination against the Minority Groups in Bosnia and Herzegovina: Barrier to EU Membership}

\author{
Bedrudin Brljavac \\ University of Sarajevo \\ Bosnia and Herzegovina
}

\begin{abstract}
Although over more than 10 years Bosnia and Herzegovina has been going through an extensive European Union-related reform process, the country is still facing serious democratic deficit. In particular, the post-Dayton public sphere has been dominated by ethno-nationalist political elites which are doing everything to exclude non-nationalists and members of minority groups from the decision-making process. This is a clear paradox since one of the main objectives behind the integration of the European countries into the European Community was to reduce disintegrative and dangerous influences of nationalists and establish a peaceful, prosperous, and secure community. In this article, we analyze the process of the post-Dayton ethno-nationalization resulting in a widespread discrimination against the so-called "others" as they are defined in the Constitution. In the post-war BiH, democratic participation has turned into a competition between the three ethnic communities, Bosniaks, Serbs, and Croats, rather than race of equal individuals having equal right of vote. That's why Bosnian people are still living under the political system which is closer to ethno-democracy or ethnocracy rather than democratic regime. Under such a discriminatory regime $\mathrm{BiH}$ can not enter the European Union, which is a model of open and democratic society.
\end{abstract}

\section{Key words:}

Democracy, Dayton Agreement, European Union, Minority Groups, Citizen, Ethno-nationalism, Group Rights, Individual Rights. 